\title{
In-hospital outcome of patients with post-MI VSD: a single-center study
}

\author{
Mohsen Abbasnejad, Mehdi Tahmasebi vand, Zhila Khamnian, Ahmad Separham \\ Department of Cardiology, Tabriz University of Medical Science, Tabriz, Iran \\ Kardiochirurgia i Torakochirurgia Polska 2018; 15 (4): 227-232
}

\begin{abstract}
Introduction: Ventricular septal defect (VSD) is a rare but lifethreatening complication of acute myocardial infarction (AMI). There is a paucity of data regarding the natural history of this devastating complication of myocardial infarction in the Middle East region with restricted financial resources and unsolved major health problems.

Aim: To evaluate the clinical presentation and in-hospital outcome of patients with post-infarction VSD over a 10-year period in a tertiary center in northwest Iran.

Material and methods: Data from 64 consecutive patients with VSD complicating AMI were retrospectively analyzed from March 2005 to May 2015.

Results: The mean age of the patients was $71.62 \pm 9.38$ years with $57.8 \%$ of them being female. The VSDs were anterior in $52(82 \%)$ patients. More than half of patients were in cardiogenic shock during the initial presentation. Multivessel coronary artery disease was found on coronary angiography in $70.3 \%$ of patients. In-hospital mortality was $82.8 \%$. Multivariate analysis revealed cardiogenic shock $(\mathrm{HR}=12.5, p=0.001)$ as the only independent predictor of in-hospital mortality and surgical treatment as the only predictor of in-hospital survival ( $\mathrm{HR}=0.2, p=0.02)$.

Conclusions: Our study demonstrated that VSD complicating myocardial infarction had an extremely high in-hospital mortality rate. Cardiogenic shock was the only independent predictor of in-hospital mortality and surgical treatment was the only predictor of in-hospital survival.
\end{abstract}

Key words: acute myocardial infarction, ventricular septal defect.

\section{Introduction}

Ventricular septal defect (VSD) is a rare but life-threatening mechanical complication of acute myocardial infarction (AMI) [1, 2]. Early reperfusion therapy including thrombolysis and primary percutaneous coronary intervention $(\mathrm{PPCl})$ has reduced the incidence of this complication from $1-2 \%$ to

\section{Streszczenie}

Wprowadzenie: Ubytek przegrody międzykomorowej (VSD) stanowi rzadkie, lecz zagrażające życiu powikłanie po przebytym ostrym zawale serca (AMI). Przy ograniczonych środkach finansowych i nierozwiązanych poważnych problemach w dziedzinie zdrowia w regionie Bliskiego Wschodu niewiele jest danych dotyczących historii tego powikłania zawału.

Cel: Ocena obrazu klinicznego i wyników szpitalnych pacjentów z VSD po AMI leczonych w ośrodku referencyjnym w północno-zachodnim Iranie w czasie 10 lat.

Materiał i metody: Analiza retrospektywna objęła 64 pacjentów z VSD po AMI leczonych od marca 2005 r. do maja 2015 r. Wyniki: Średnia wieku pacjentów wynosiła 71,62 $\pm 9,38$ roku, kobiety stanowity 57,8\% badanych. U 52 (82\%) pacjentów występował przedni ubytek przegrody międzykomorowej. Ponad połowa pacjentów była podczas wstępnego badania we wstrząsie kardiogennym. U 70,3\% pacjentów stwierdzono w koronarografii wielonaczyniową chorobę wieńcową. Śmiertelność szpitalna wynosiła $82,8 \%$. W analizie wielowymiarowej wykazano, że wstrząs kardiogenny ( $H R=12,5, p=0,001)$ stanowi jedyny niezależny czynnik prognostyczny śmiertelności szpitalnej, a leczenie chirurgiczne - jedyny czynnik prognostyczny przeżycia w szpitalu (HR $=0,2, p=0,02)$.

Wnioski: W badaniu wykazano, że VSD jako powikłanie po przebytym zawale charakteryzuje się niezwykle wysokim wskaźnikiem śmiertelności szpitalnej. Wstrząs kardiogenny był jedynym niezależnym czynnikiem prognostycznym śmiertelności szpitalnej, a leczenie chirurgiczne - jedynym czynnikiem prognostycznym przeżycia w szpitalu.

Słowa kluczowe: ostry zawał serca, ubytek przegrody międzykomorowej.

$0.2 \%$ [2-4]. However, the mortality rate of VSD associated with conservative or surgical management is still high [5]. There is a paucity of data regarding the natural history of this devastating complication of myocardial infarction in the Middle East region with restricted financial resources and unsolved major health problems. For example, about

Address for correspondence: Ahmad Separham, Department of Cardiology, Tabriz University of Medical Science, Madani Heart Center, Daneshgah Ave, 5166614756 Tabriz, Iran, phone: +98 914300439, e-mail: aseparham@gmail.com Received: 3.09.2018, accepted: 17.11.2018. 
$10-15 \%$ of the Iranian population have no health insurance coverage at all [6]. Not surprisingly, health expenditure per capita is about US\$ 350 in Iran, far less than European and North American countries [7]. Also, there are limited data regarding outcome and valuation of cardiac surgical procedures in Iran as one study reported in-hospital mortality of $0.47 \%$ for isolated coronary artery bypass grafting (CABG) surgery [8] but the presentation and management of postMI VSD remain largely unknown.

\section{Aim}

So, in the present study, we aimed to evaluate the clinical presentation and in-hospital outcome of patients with post-infarction VSD over a 10 -year period in a tertiary center in northwest Iran.

\section{Material and methods}

Between March 2005 and May 2015, data from 64 consecutive patients with VSD complicating AMI were retrospectively collected and analyzed in our hospital. During this period, 9697 patients were admitted to our center with diagnosis of AMI. So, the overall incidence of postMI ventricular septal defect was $0.65 \%$. The present study

Table I. Baseline characteristics of patients

\begin{tabular}{|c|c|c|}
\hline \multicolumn{2}{|l|}{ Parameter } & Value \\
\hline \multicolumn{2}{|c|}{ Age, mean \pm SD [years] } & $71.62 \pm 9.38$ \\
\hline \multirow[t]{2}{*}{ Gender, $n(\%)$} & Male & $27(42.2)$ \\
\hline & Female & $37(57.8)$ \\
\hline \multicolumn{2}{|c|}{ Diabetes mellitus, $n$ (\%) } & $12(18.8)$ \\
\hline \multicolumn{2}{|l|}{ Hyperlipidemia, $n$ (\%) } & $17(26.6)$ \\
\hline \multicolumn{2}{|l|}{ Hypertension, $n$ (\%) } & $39(60.9)$ \\
\hline \multicolumn{2}{|l|}{ Renal failure, $n(\%)$} & $15(23.4)$ \\
\hline \multicolumn{2}{|c|}{ Previous myocardial infarction or angina, $n(\%)$} & $16(25)$ \\
\hline \multicolumn{2}{|c|}{ Systolic blood pressure [mm Hg] } & $100.98 \pm 21.69$ \\
\hline \multicolumn{2}{|c|}{ Diastolic blood pressure [mm Hg] } & $65.28 \pm 13.64$ \\
\hline \multicolumn{2}{|l|}{ Heart rate $[\mathrm{bpm}]$} & $94.04 \pm 20.97$ \\
\hline \multirow[t]{2}{*}{ VSD location, $n(\%)$} & Anterior & $53(82.81)$ \\
\hline & Non-anterior & $11(17.19)$ \\
\hline \multirow{3}{*}{$\begin{array}{l}\text { Number of diseased } \\
\text { vessels, } n(\%)\end{array}$} & 1 & $19(29)$ \\
\hline & 2 & $27(42)$ \\
\hline & 3 & $18(29)$ \\
\hline \multirow[t]{3}{*}{ Culprit vessel } & LAD & $53(82.81)$ \\
\hline & $\mathrm{LCX}$ & $3(4.68)$ \\
\hline & RCA & $8(12.5)$ \\
\hline \multicolumn{2}{|l|}{ Reperfusion, $n(\%)$} & $22(34.4)$ \\
\hline \multirow{2}{*}{$\begin{array}{l}\text { Type of reperfusion, } \\
n(\%)\end{array}$} & Thrombolysis & $20(31.3)$ \\
\hline & Primary $\mathrm{PCl}$ & $2(3.1)$ \\
\hline
\end{tabular}

VSD - ventricular septal defect, $\mathrm{PCl}$ - percutaneous coronary intervention, LAD - left anterior descending artery, LCX - left circumflex artery, RCA - right coronary artery. was approved by the ethics committee of Tabriz University of Medical Sciences (Study No. 94/1-7/4). Written informed consent was obtained from all patients or the patient's relatives. The diagnosis of AMI was based on prolonged anginal chest pain, electrocardiographic signs of infarction, and a documented rise of cardiac enzymes. The VSD was diagnosed by transthoracic echocardiogram as disrupted ventricular septum with evidence of left-to-right shunt by color Doppler in all cases. Left ventricular systolic function was calculated using Simpson's method.

Demographic data, coronary risk factors, Killip class, hemodynamic status on hospital admission, reperfusion therapy, and angiographic data including culprit vessel, echocardiographic findings, and intra-aortic balloon pump usage were recorded. Long-term follow-up was done by phone contact and regular visits among patients who were discharged home alive. All patients underwent coronary angiography. Coronary artery stenosis more than $70 \%$ was considered significant and multivessel coronary artery disease was defined as stenosis of $>70 \%$ in two or more major coronary arteries. Right heart catheterization was performed in 34 patients. Left-to-right shunt estimation was performed by catheterization data or echocardiographic finding. Cardiogenic shock was defined as systolic blood pressure less than $90 \mathrm{~mm} \mathrm{Hg}$ associated with signs of hypoperfusion including cold extremities, altered mental status, and reduced urine output [9]. Renal failure was defined as serum creatinine more than $1.5 \mathrm{mg} / \mathrm{dl}$ or need for renal replacement therapy. The primary outcome was in-hospital mortality. Also, several demographic, hemodynamic, angiographic, and echocardiographic variables were compared between in-hospital survivors and the non-survivor group and between the surgical treatment group and the medical treatment group.

\section{Statistical analysis}

Categorical variables were expressed as a percentage and continuous variables were presented as mean \pm standard deviation (SD). The chi-square $\left(\chi^{2}\right)$ or Fisher's exact test was used to compare categorical variables and the Mann-Whitney U-test and Student's $t$-test were used to compare continuous variables. Predictors of mortality in univariate analysis with a $p$-value less than 0.05 were included in the multivariate model. Multivariate logistic regression was used to estimate independent risk factors for the factors with a significant $p$-value $(<0.05)$ through a univariate analysis. $P$-values less than 0.05 were considered statistically significant. All data were analyzed using SPSS version 18 (SPSS Inc, Chicago, IL).

\section{Results}

The mean age of the patients was $71.62 \pm 9.38$ years with $57.8 \%$ females. Demographic, hemodynamic, echocardiographic, and angiographic findings are shown in Table I. Most patients were above 60 years old (85\%). The VSDs were anterior in $53(82.81 \%)$ patients. The VSD size in most cases was $>10 \mathrm{~mm}$. A total of $41(64.1 \%)$ patients were in cardiogenic shock during initial presentation. Totally, 
22 patients developed post-MI VSD after reperfusion therapy. Twenty patients received thrombolysis, of whom 15 were referred from another center after lytic therapy and development of VSD. Five patients received thrombolysis in our center and subsequently were found to have post-MI VSD. Mean door-to-needle time was $89 \pm 13$ min. Two patients developed VSD after being treated with primary angioplasty in our center. These 2 patients presented more than $12 \mathrm{~h}$ after initiation of chest pain and mean door-to-balloon time was $101 \pm 4 \mathrm{~min}$. Forty-two patients did not receive any type of reperfusion therapy, of whom 11 patients were referred from other centers and the remainder presented initially at our hospital. Because of the poor hemodynamic status of most patients, apart from ASA, statin, IV nitrate, furosemide and inotropes no other medication was used except clopidogrel in 2 patients who underwent coronary angioplasty. Multivessel coronary artery disease was found on coronary angiography in $70.3 \%$ of patients. Preoperative mean pulmonary artery pressure was $44.1 \pm 7.9 \mathrm{~mm} \mathrm{Hg}$ and mean left to right shunt was $3.5 \pm 1.2$.

An intra-aortic balloon pump (IABP) was used in 30 (46\%) cases. Other types of mechanical circulatory support were not available in our center mainly due to limited financial resources. Surgical treatment was performed in 23 (35.9\%) out of 64 cases including VSD repair in 8 (12.5\%) patients and coronary artery bypass graft (CABG) (mean 1.4 grafts per patient) with VSD repair in 15 (23.4\%) patients. All operations were performed via median sternotomy and hypothermic cardiopulmonary bypass was applied. Myocardial protection was provided with cold cardioplegia. Mean cardiopulmonary bypass time was $153 \pm 42.1 \mathrm{~min}$ and mean aortic cross clamp time was $74 \pm 37$ min. All grafts were saphenous veins. The two main techniques used for surgical repair were: 1) infarct excision (Daggett procedure) [10] with single Dacron patch repair in 14 patients and 2) infarct exclusion (David procedure) [11, 12] with bovine pericardial patch repair in 9 patients. Sandwich repair was not performed in these series as our surgeons are not familiar with this technique $[13,14]$. Daggett procedure and David approach had a mortality rate of $57.1 \%(8 / 14)$ and $55.5 \%$ (5/9) respectively. All of the surgical interventions were done during the index hospitalization and were not delayed. Thirteen (56.5\%) patients of the surgically treated group died. The remaining patients (41/64) did not receive surgical treatment; all but one of them died (97.65\%). The main reasons for not performing surgical treatment were as follows: Ten patients refused surgery. In the remaining patients, the treating surgical team considered surgery too high risk mainly due to unstable hemodynamics and extreme frailty and advised conservative management. None of our patients underwent device closure. In-hospital mortality was $82.8 \%$. Mean duration of hospital stay was 6.96 \pm 5.63 days. Long-term follow-up showed that all 11 patients who survived the hospital course were alive at the time of writing this report and had NYHA FC II-III symptoms. We also compared baseline characteristics between surgical and medical treatment groups and it revealed that patients who underwent surgery were younger, had more preserved left ventricular function and more received IABP than patients with conservative management. Also male gender and single vessel coronary involvement were more common in this group (Table II).

Table III demonstrates baseline and clinical findings between survivor and non-survivor groups. Univariate predictors of in-hospital mortality were as follows: advanced age, female gender, lower systolic blood pressure at initial presentation, multivessel coronary stenosis, cardiogenic shock and no surgical treatment. The six above-mentioned factors were included in the multivariate analysis to predict independent factors associated with in-hospital mortality. Multivariate logistic regression analysis revealed cardiogenic shock as an independent predictor of in-hospital mortality and surgical treatment as a predictor of in-hospital survival (Table IV).

The mortality rate among patients with and without cardiogenic shock was 39/41 (95.1\%) and 14/23 (60.9\%), respectively $(p=0.001)$.

\section{Discussion}

The main findings of the present study are as follows: 1) post-MI ventricular septal defect had extremely high in-hospital mortality; 2) more than half of the patients in the present study were in cardiogenic shock in hospital admission; 3) cardiogenic shock was the only independent predictor of hospital death and surgical treatment as the main predictor of survival; 4) overall, fewer sick patients underwent surgery as evident by younger age, better left ventricular function, more common single vessel disease and male gender and IABP insertion was more common in this group.

Our study showed high in-hospital mortality among patients with a post-MI ventricular septal defect. This result is in line with some prior studies [15-19] while contradicting others [20-23]. The causes of high mortality rate in the present study may be related to multiple factors including older age, unstable hemodynamics, advanced coronary involvement, and underuse of support devices. Like previous studies [24, 25], our cohort mainly consisted of older patients and females, which are known risk factors for mortality in post-MI VSD. The other main cause of high mortality is compromised hemodynamic status during initial presentation. More than $60 \%$ of patients in the present study were in cardiogenic shock at hospital admission and, like previous reports, this independently predicted in-hospital mortality [26-29]. Cardiogenic shock and low blood pressure usually lead to more left ventricular dysfunction due to reduced coronary perfusion, which is followed by multi-organ failure and death.

Unlike some previous studies [2, 18, 19, 26, 30] but in agreement with others [15, 20, 23, 31, 32], multivessel coronary artery disease was more common in our cohort and was associated with in-hospital mortality in the univariate analysis. Advanced coronary artery stenosis may induce global left ventricular ischemia and necrosis and thus lead to the development of pump failure and cardiogenic shock. 
Table II. Baseline characteristics in surgical versus medical groups

\begin{tabular}{|c|c|c|c|c|}
\hline Parameter & & $\begin{array}{l}\text { Surgical group } \\
\qquad(n=23)\end{array}$ & $\begin{array}{l}\text { Medical group } \\
\quad(n=41)\end{array}$ & $P$-value \\
\hline Age [years] & & $67.43 \pm 9.33$ & $73.97 \pm 8.67$ & 0.006 \\
\hline \multirow[t]{2}{*}{ Gender } & Male & $14(60.9 \%)$ & $13(31.7 \%)$ & \multirow[t]{2}{*}{0.02} \\
\hline & Female & $9(39.1 \%)$ & $28(68.3 \%)$ & \\
\hline Diabetes mellitus & & $6(26.1 \%)$ & $6(14.6 \%)$ & 0.26 \\
\hline Hypertension & & $13(56.5 \%)$ & $26(63.4 \%)$ & 0.58 \\
\hline Hyperlipidemia & & $7(30.4 \%)$ & $10(24.4 \%)$ & 0.59 \\
\hline Previous MI & & $4(17.4 \%)$ & $12(29.3 \%)$ & 0.29 \\
\hline Systolic blood pressure [mm Hg] & & $104.69 \pm 19.15$ & $98.90 \pm 22.95$ & 0.30 \\
\hline Diastolic blood pressure [mm Hg] & & $67.73 \pm 13.53$ & $63.90 \pm 13.67$ & 0.28 \\
\hline Heart rate $[\mathrm{bpm}]$ & & $95.86 \pm 18.56$ & $93.02 \pm 22.36$ & 0.60 \\
\hline \multirow[t]{2}{*}{ MI } & Anterior & $19(82.6 \%)$ & $34(82.9 \%)$ & \multirow[t]{2}{*}{0.97} \\
\hline & Non-anterior & $4(17.4 \%)$ & $7(17.1 \%)$ & \\
\hline \multirow[t]{2}{*}{ Killip class } & I, II & $5(21.7 \%)$ & $11(26.8 \%)$ & \multirow[t]{2}{*}{0.65} \\
\hline & III, IV & $18(78.3 \%)$ & $30(73.2 \%)$ & \\
\hline \multirow[t]{2}{*}{ Number of diseased vessels } & Single vessel & $11(47.8 \%)$ & $8(19.5 \%)$ & \multirow[t]{2}{*}{0.01} \\
\hline & Multivessel & $12(52.2 \%)$ & $33(80.5 \%)$ & \\
\hline Reperfusion & & 7 (30.4\%) & $15(36.6 \%)$ & 0.61 \\
\hline \multirow[t]{2}{*}{ LVEF } & $>45 \%$ & $6(26.1 \%)$ & $3(7.3 \%)$ & \multirow[t]{2}{*}{0.03} \\
\hline & $<45 \%$ & 17 (73.9\%) & $38(92.7 \%)$ & \\
\hline \multirow[t]{2}{*}{ VSD size $[\mathrm{mm}]$} & $5-10$ & $4(17.4 \%)$ & $6(14.6 \%)$ & \multirow[t]{2}{*}{0.77} \\
\hline & $>10$ & $19(82.6 \%)$ & 35 (85.45\%) & \\
\hline \multirow[t]{2}{*}{ Time of onset of VSD [days] } & $<4$ & $23(100 \%)$ & 37 (90.2\%) & \multirow[t]{2}{*}{0.12} \\
\hline & $\geq 4$ & 0 & $4(9.8 \%)$ & \\
\hline IABP & & $16(69.6 \%)$ & $14(34.1 \%)$ & 0.006 \\
\hline Cardiogenic shock & & $14(60.9 \%)$ & $27(65.9 \%)$ & 0.69 \\
\hline Renal failure & & $5(21.7 \%)$ & $10(24.3 \%)$ & 1.0 \\
\hline
\end{tabular}

MI - myocardial infarction, VSD - ventricular septal defect, LVEF - left ventricular ejection fraction, IABP - intra-aortic balloon pump.

One possible explanation for high in-hospital mortality in the present study may be the underuse of mechanical support devices including the IABP. Mechanical support devices may have a role in the management of mechanical complication of acute myocardial infarction as a bridge to surgery [33-35]. Less than half of our patients received an IABP while other types of support devices such as extracorporeal membrane oxygenation (ECMO) and ventricular assist devices (VAD) were not available during the study period in our hospital mainly due to limited financial resources. Thus, the high mortality rate of patients is not surprising. Another probable main reason for the complicated hospital course in the present study may be related to the more conservative treatment of the entire cohort. As most patients were critically unstable, medical treatment was of no value in them and failure of this approach led to high mortality. Based on Table II, other possible reasons for the lower survival rate in patients treated medically may be more advanced age and coronary artery disease in these patients as well as less cardiac reserve and less support with IABP. Results of the present study questioned the "late surgery approach" as many authors have recommend de- layed surgery for healing of necrotic myocardium and stabilization of the patient [20, 22, 28, 36]. Based on the present study it seems unreasonable to delay surgery in patients with post-MI ventricular septal defect as these patients will never be really stabilized. So, early surgery planning after diagnosis of this devastating complication should be considered [37].

This study has some limitations. First, the research population was relatively small, limiting its statistical power. Second, this was a single-center nonrandomized observational retrospective study, but due to the grave nature of this complication of myocardial infarction, conducting a randomized trial in this setting may be very difficult or even impossible. Third, a small number of patients underwent surgery. There was no significant difference regarding mortality between two common procedures used by our surgical team and newer techniques like the sandwich procedure were not performed in the period of the study, which may be responsible for higher mortality even in surgically treated patients. So, the impact of surgical approaches and techniques needs further large scale studies. 
Table III. Univariate analysis for in-hospital mortality

\begin{tabular}{|c|c|c|c|c|}
\hline \multicolumn{2}{|l|}{ Parameter } & $\begin{array}{c}\text { Non-survivors } \\
\quad(n=53)\end{array}$ & $\begin{array}{l}\text { Survivors } \\
(n=11)\end{array}$ & $P$-value \\
\hline \multicolumn{2}{|l|}{ Age [years] } & $72.88 \pm 8.82$ & $65.54 \pm 10.05$ & 0.01 \\
\hline \multirow[t]{2}{*}{ Gender } & Male & $19(35.8 \%)$ & $8(72.7 \%)$ & \multirow[t]{2}{*}{0.04} \\
\hline & Female & $34(64.2 \%)$ & $3(27.3 \%)$ & \\
\hline \multicolumn{2}{|l|}{ Diabetes mellitus } & $9(17 \%)$ & $3(27.3 \%)$ & 0.41 \\
\hline \multicolumn{2}{|l|}{ Hypertension } & $34(64.2 \%)$ & $5(45.5 \%)$ & 0.31 \\
\hline \multicolumn{2}{|l|}{ Hyperlipidemia } & $15(28.3 \%)$ & $2(18.2 \%)$ & 0.71 \\
\hline \multicolumn{2}{|c|}{ Systolic blood pressure [mm Hg] } & $98.54 \pm 21.81$ & $112.72 \pm 17.51$ & 0.04 \\
\hline \multicolumn{2}{|c|}{ Diastolic blood pressure [mm Hg] } & $64.05 \pm 14.25$ & $71.18 \pm 8.32$ & 0.11 \\
\hline \multicolumn{2}{|l|}{ Heart rate $[\mathrm{bpm}]$} & $94.54 \pm 21.44$ & $91.63 \pm 19.27$ & 0.67 \\
\hline \multicolumn{2}{|l|}{ Renal failure } & $12(22.6 \%)$ & $3(27.2 \%)$ & 0.7 \\
\hline \multirow[t]{2}{*}{ MI } & Anterior & $44(83 \%)$ & $9(81.8 \%)$ & \multirow[t]{2}{*}{0.92} \\
\hline & Non-anterior & $9(17 \%)$ & $2(18.2 \%)$ & \\
\hline \multicolumn{2}{|l|}{ Killip class > II } & $42(79.2 \%)$ & $6(54.5 \%)$ & 0.08 \\
\hline \multirow[t]{2}{*}{ Number of diseased vessels } & Single vessel & $12(22.6 \%)$ & 7 (63.6\%) & \multirow[t]{2}{*}{0.01} \\
\hline & Multivessel & $41(77.4 \%)$ & $4(36.4 \%)$ & \\
\hline \multicolumn{2}{|l|}{ Reperfusion } & $17(32.1 \%)$ & $5(45.5 \%)$ & 0.49 \\
\hline \multicolumn{2}{|l|}{ LVEF, mean \pm SD (\%) } & $38.4 \pm 6.9$ & $39.7 \pm 6.3$ & 0.56 \\
\hline \multicolumn{2}{|l|}{ VSD size, mean \pm SD [mm] } & $11.7 \pm 5$ & $11.6 \pm 3$ & 0.94 \\
\hline \multicolumn{2}{|c|}{ Time between MI and VSD, mean \pm SD [days] } & $2.7 \pm 1.6$ & $2.9 \pm 1.3$ & 0.69 \\
\hline \multicolumn{2}{|l|}{ IABP } & $25(47.2 \%)$ & $5(45.5 \%)$ & 0.91 \\
\hline \multicolumn{2}{|l|}{ Cardiogenic shock } & $39(73.6 \%)$ & $2(18.2 \%)$ & $<0.001$ \\
\hline \multicolumn{2}{|l|}{ Surgical treatment } & $13(24.5 \%)$ & $10(90.9 \%)$ & $<0.001$ \\
\hline
\end{tabular}

MI - myocardial infarction, VSD - ventricular septal defect, LVEF - left ventricular ejection fraction, IABP - intra-aortic balloon pump.

\section{Conclusions}

Our study demonstrated an extremely high in-hospital mortality rate associated with VSD complicating myocardial infarction. Cardiogenic shock was the only independent predictor of in-hospital mortality and surgical treatment was a predictor of in-hospital survival.

\section{Disclosure}

The authors report no conflict of interest.

\section{References}

1. Topaz O, Taylor AL. Interventricular septal rupture complicating acute myocardial infarction: from pathophysiologic features to the role of invasive and noninvasive diagnostic modalities in current management. Am J Med 1992; 93: 683-688

2. Crenshaw BS, Granger CB, Birnbaum Y, Pieper KS, Morris DC, Kleiman NS, Vahanian A, Califf RM, Topol EJ. Risk factors, angiographic patterns, and outcomes in patients with ventricular septal defect complicating acute myocardial infarction. GUSTO-I (Global Utilization of Streptokinase and TPA for Occluded Coronary Arteries) Trial Investigators. Circulation 2000; 101: 27-32.

3. Moreyra AE, Huang MS, Wilson AC, Deng Y, Cosgrove NM, Kostis JB; MIDAS Study Group (MIDAS 13). Trends in incidence and mortality rates of ventricular septal rupture during acute myocardial infarction. Am J Cardiol 2010; 106: 1095-1100.
Table IV. Multivariate regression analysis of independent predictors of in-hospital mortality

\begin{tabular}{|c|c|c|c|c|}
\hline \multirow[t]{2}{*}{ Variable } & \multirow{2}{*}{$\begin{array}{l}\text { Odds } \\
\text { ratio }\end{array}$} & \multicolumn{2}{|c|}{$95 \%$ Confidence interval } & \multirow[t]{2}{*}{$P$-value } \\
\hline & & Lower & Upper & \\
\hline Age & 0.901 & 0.742 & 1.094 & 0.29 \\
\hline Gender & 0.731 & 0.038 & 1.997 & 0.83 \\
\hline $\begin{array}{l}\text { Systolic blood } \\
\text { pressure }\end{array}$ & 1.005 & 0.939 & 1.076 & 0.88 \\
\hline $\begin{array}{l}\text { Multivessel } \\
\text { disease }\end{array}$ & 0.366 & 0.058 & 2.302 & 0.28 \\
\hline Cardiogenic shock & 12.536 & 2.409 & 65.233 & 0.003 \\
\hline Surgical treatment & 0.201 & 0.52 & 0.782 & 0.02 \\
\hline
\end{tabular}

4. French JK, Hellkamp AS, Armstrong PW, Cohen E, Kleiman NS, O'Connor CM, Holmes DR, Hochman JS, Granger CB, Mahaffey KW. Mechanical complications after percutaneous coronary intervention in ST-elevation myo cardial infarction (from APEX-AMI). Am J Cardiol 2010; 105: 59-63.

5. Birnbaum Y, Fishbein MC, Blanche C, Siegel RJ. Ventricular septal rupture after acute myocardial infarction. N Engl J Med 2002; 347: 1426-1432.

6. Davari M, Haycox A, Walley T. The Iranian health insurance system; past experiences, present challenges and future strategies. Iran J Public Health 2012; 41: 1-9.

7. Khosravi B, Soltani S, Javan-Noughabi J. Health care expenditure in the Islamic Republic of Iran versus other high spending countries. Med J Islam Repub Iran 2017; 31: 71. 
8. Abbasi K, Karimi A, Abbasi SH, Ahmadi SH, Davoodi S, Babamahmoodi A, Movahedi N, Salehiomran A, Shirzad M, Bina P. Knowledge management in cardiac surgery: the second Tehran Heart Center adult cardiac surgery database report. J Tehran Heart Cent 2012; 7: 111-116.

9. Westaby S, Kharbanda R, Banning AP. Cardiogenic shock in ACS. Part 1: prediction, presentation and medical therapy. Nat Rev Cardiol 2011; 9: 158-171.

10. Daggett WM, Guyton RA, Mundth ED, Buckley MJ, McEnany MT, Gold HK, Leinbach RC, Austen WG. Surgery for post-myocardial infarct ventricular septal defect. Ann Surg 1977; 186: 260-271.

11. David TE, Dale L, Sun Z. Postinfarction ventricular septal rupture: repair by endocardial patch with infarct exclusion. J Thoracic Cardiovasc Surg 1995; 110: 1315-1322.

12. Isoda S, Osako M, Kimura T, Nishimura K, Yamanaka N, Nakamura S, Maehara T. Surgical repair of postinfarction ventricular septal defects-2013 update. Ann Thorac Cardiovasc Surg 2013; 19: 95-102.

13. Isoda S, Imoto K, Uchida K, Nishimura K, Karube N, Suzuki S, Masuda M. "Sandwich technique" via a right ventricle incision to repair postinfarction ventricular septal defects. J Card Surg 2015; 30: 488-493.

14. Isoda S, Imoto K, Uchida K, Karube N, Kasama K, Yamazaki I, Suzuki S, Yano Y, Matsuki Y, Masuda M. Pitfalls for the "Sandwich technique" via a right ventricular incision to repair post- infarction ventricular septal defects. Gen Thorac Cardiovasc Surg 2017; 65: 187-193.

15. Yip HK, Wu CJ, Chang HW, Wang CP, Cheng Cl, Chua S, Chen MC. Cardiac rupture complicating acute myocardial infarction in the direct percutaneous coronary intervention reperfusion era. Chest 2003; 124: 565-571.

16. Nozoe M, Sakamoto T, Taguchi E, Miyamoto S, Fukunaga T, Nakao K. Clinical manifestation of early phase left ventricular rupture complicating acute myocardial infarction in the primary PCl era. J Cardiol 2014; 63: 14-18.

17. Poulsen SH, Praestholm M, Munk K, Wierup P, Egeblad H, Nielsen-Kudsk JE. Ventricular septal rupture complicating acute myocardial infarction: clinical characteristics and contemporary outcome. Ann Thorac Surg 2008; 85: 15911596.

18. Malhotra A, Patel K, Sharma P, Wadhawa V, Madan T, Khandeparkar J, Shah K, Patel S. Techniques, timing and prognosis of post infarct ventricular septal repair: a re-look at old dogmas. Braz J Cardiovasc Surg 2017; 32: 147-155.

19. Menon V, Webb JG, Hillis LD, Sleeper LA, Abboud R, Dzavik V, Slater JN, Forman R, Monrad ES, Talley JD, Hochman JS. Outcome and profile of ventricular septal rupture with cardiogenic shock after myocardial infarction: a report from the SHOCK Trial Registry. J Am Coll Cardiol 2000; 36 (3 Suppl A): 11101116.

20. Serpytis P, Karvelyte N, Serpytis R, Kalinauskas G, Rucinskas K, Samalavicius R, Ivaska J, Glaveckaite S, Berukstis E, Tubaro M, Alpert JS, Laucevičius A. Post-infarction ventricular septal defect: risk factors and early outcomes. Hellenic J Cardiol 2015; 56: 66-71.

21. Yalçınkaya A, Lafçı G, Diken Ai, Aksoy E, Çiçek ÖF, Lafçı A, Korkmaz K, Çağı K. Early mortality and long-term survival after repair of post-infarction ventricular septal rupture: an institutional report of experience. Heart Lung Circ 2016; 25: 384-391.

22. Coskun KO, Coskun ST, Popov AF, Hinz J, Schmitto JD, Bockhorst K, Stich KM, Koerfer R. Experiences with surgical treatment of ventricle septal defect as a postinfarction complication. J Cardiothorac Surg 2009; 4: 3.

23. Pang PY, Sin YK, Lim CH, Tan TE, Lim SL, Chao VT, Su JW, Chua YL. Outcome and survival analysis of surgical repair of post-infarction ventricular septal rupture. J Cardiothorac Surg 2013; 8: 44.
24. Cinq-Mars A, Voisine P, Dagenais F, Charbonneau É, Jacques F, Kalavrouziotis D, Perron J, Mohammadi S, Dubois M, Le Ven F, Poirier P, O'Connor K, Bernier M, Bergeron S, Sénéchal M. Risk factors of mortality after surgical correction of ventricular septal defect following myocardial infarction: retrospective analysis and review of the literature. Int J Cardiol 2016; 206: 27-36.

25. Ledakowicz-Polak A, Polak L, Zielińska M. Ventricular septal defect complicating acute myocardial infarction - still an unsolved problem in the invasive treatment era. Cardiovasc Pathol 2011; 20: 93-98.

26. Deja MA, Szostek J, Widenka K, Szafron B, Spyt TJ, Hickey MS, Sosnowski AW. Post infarction ventricular septal defect - can we do better? Eur J Cardiothorac Surg 2000; 18: 194-201.

27. Labrousse L, Choukroun E, Chevalier JM, Madonna F, Robertie F, Merlico F, Coste P, Deville C. Surgery for postinfarction ventricular septal defect (VSD): risk factors for hospital death and long-term results. Eur J Cardiothorac Surg 2002; 21: 725-731.

28. Arnaoutakis GJ, Zhao Y, George TJ, Sciortino CM, McCarthy PM, Conte JV. Surgical repair of ventricular septal defect after myocardial infarction: outcomes from the Society of Thoracic Surgeons National Database. Ann Thorac Surg 2012; 94: 436-443.

29. Sibal AK, Prasad S, Alison P, Nand P, Haydock D. Acute ischemic ventricular septal defect: a formidable surgical challenge. Heart Lung Circ 2010; 19: 71-74.

30. Leavey S, Galvin J, McCann H, Sugrue D. Post-myocardial infarction ventricular septal defect: an angiographic study. Ir J Med Sci 1994; 163: 182-183.

31. Papadopoulos N, Moritz A, Dzemali O, Zierer A, Rouhollapour A, Ackermann $\mathrm{H}$, Bakhtiary F. Long-term results after surgical repair of postinfarction ventricular septal rupture by infarct exclusion technique. Ann Thorac Surg 2009; 87: 1421-1425.

32. Huang SM, Huang SC, Wang CH, Wu IH, Chi NH, Yu HY, Hsu RB, Chang Cl, Wang SS, Chen YS. Risk factors and outcome analysis after surgical management of ventricular septal rupture complicating acute myocardial infarction: a retrospective analysis. J Cardiothorac Surg 2015; 10: 66.

33. Liebelt JJ, Yang Y, DeRose JJ, Taub CC. Ventricular septal rupture complicating acute myocardial infarction in the modern era with mechanical circulatory support: a single center observational study. Am J Cardiovasc Dis 2016; 6: 10-16.

34. Faber C, McCarthy PM, Smedira NG, Young JB, Starling RC, Hoercher KJ. Implantable left ventricular assist device for patients with postinfarction ventricular septal defect. J Thorac Cardiovasc Surg 2002; 124: 400-401.

35. Neragi-Miandoab S, Michler RE, Goldstein D, D’Alessandro D. Extracorporeal membrane oxygenation as a temporizing approach in a patient with shock, myocardial infarct, and a large ventricle septal defect: successful repair after six days. J Card Surg 2013; 28: 193-195.

36. Jeppsson A, Liden H, Johnsson P, Hartford M, Rådegran K. Surgical repair of postinfarction ventricular septal defects: a national experience. Eur J Cardiothorac Surg 2005; 27: 216-221.

37. Papalexopoulou N, Young CP, Attia RQ. What is the best timing of surgery in patients with post-infarct ventricular septal rupture? Interactive Cardiovasc Thoracic Surg 2013; 16: 193-196. 